\title{
中国地方における学童保育施設の自治体及び小学校区単位の整備状況
}

\section{SUPPLY SITUATION OF SCHOOLCHILD CARE FACILITY BY LOCAL GOVERNMENT AND ELEMENTARY SCHOOL UNIT IN CHUGOKU DISTRICT}

\author{
孔相 権*, 草野啓太覀, 中園眞人***, 山本幸子****, 牛島 朗***** \\ Syohken KOH, Keita KUSANO, Mahito NAKAZONO, \\ Sachiko YAMAMOTO and Akira USHIJIMA
}

\begin{abstract}
The purpose of this study is to clarify the regionality of schoolchild care facility supply situation of the old local government unit and to estimate the number of registered children of the elementary school district unit in Chugoku district 5 prefectures, and to consider the supply method of schoolchild care facility for the future. Each old local government in 2000 was able to classify into five types, called Urban type, Flat-ground type, Middle type, Mountainous type A, and Mountainous type B. Although a schoolchild care facility is established in an elementary school by all the types in many cases, the rate that a facility is established out of an elementary school increases in Mountainous type A and B. By estimating the number of registered children, it is clarified that the disparity between urban type and mountainous type is large, and that the supply method according to each type is required.
\end{abstract}

Keywords : Schoolchild Care Facility, Regionality, Registered Children, Chugoku District, Facility Supply 学童保育施設，地域性， 登録児童，中国地方，施設整備

\section{1. 序論}

共働き世帯の増加などの世帯内の就労形態の変化と、核家族化や 1 人親世帯の増加などの世帯構造の変化により、小学校低学年の览 童に放課後の保育サービスや遊び場を提供する学童保育施設への社 会的ニーズは高まっており、学童保育施設の量的・質的拡充が望ま れている。こうした需要の高まりにより、1950 年代に父母会等の運 営により始まった学童保育施設は、1997 年に児童福祉法に位置づけ られ制度化され、以後、小学校内を中心に急速に施設整備が進めら れ、2014 年時点で全国に約 2 万 2,000 施設が開設され一定の成果を あげている ${ }^{1)}$ 。しかし、全国学童保育連絡協議会によると潜在的な 待機児童数は約 40 万人注 1$)$ と推計されており、需要の増加に対して 施設整備が追いつかず、量的拡充のため施設定員を増やすまたは定 員を定めないことにより対応する自治体も多く、都市地域を中心に 施設の大規模化・過密化が深刻な課題として指摘されてきた。

厚生労働省もこうした指摘に対応するため、2007 年に学童保育施 設の設置・運営基準を示したガイドライン注 2) を策定したが、法的 拘束力のない推奨基準を示すにとどまり、学童保育施設の質的拡充 への対応は遅れていた。しかし、2014 年の児童福祉法改正により、 2015 年 4 月から学童保育施設の対象児童学年が 6 年生にまで引き上 げられ、施設定員や 1 人当り専用区画面積がガイドラインの推奨值 から設置基準注 3) として明確に示されたことより、今後、施設の大 規模化・過密化には一定の歯止めがかかり質的拡充につながること
が期待される。こうした大規模化・過密化が課題として指摘される 地域がある一方、児童数が少ない過疎地域を中心に施設整備そのも のが進まない空白地域も存在しており、2010 年の国民生活センター が行った調查報告 ${ }^{2)}$ では「必要とする子どもが利用できるように学 童保育サービスの空白自治体を解消寸ること」が提言されている。 学童保育施設の整備状況の地域間格差は大きく、格差を解消寸るた めには、広域的取り組みを行う都道府県や国と具体的に施設整備を 行う市区町村との連携が必要であると考えられる。

学童保育施設に関する既往研究には、使われ方調查をもとに保育 施設の空間構成のあり方を論じた研究 ${ }^{3)}$ 、保育空間の分割方法と効 果を検討した研究 ${ }^{4)}$ 、民家改修型の施設を事例に 2 室 3 領域型の空 間構成の有効性を指摘した研究 ${ }^{5)}$ 、遊びの種類による施設類型から 所要面積の算出を試みた研究 ${ }^{6)}$ 、览童の行為に要する面積より必要 面積を検討した研究 ${ }^{7)}$ 、東京都内の全学童施設を対象にアンケート 調查を行い施設運営実態より適切な人数・面積規模を検討した研究 8) 等、施設の空間構成や施設規模を論じた研究成果が蓄積されてい る。一方、自治体を対象とした整備状況に関寸る研究には、人口規 模別に地方自治体の施設整備状況を把握しガイドラインへの対応と 今後の施設整備方針を明らかにした研究 ${ }^{9)}$ 等が確認できるが、全体 的に研究蓄積は少なく、地域間格差を明らかにした上で、地域の実 情に合致した施設整備の方向を検討することが課題といえる。

そこで本論では、中国地方 5 県を対象に、旧自治体単位で地域条

\footnotetext{
* 山口大学大学院理工学研究科 講師 ·博士 (工学)

** (株)内藤建築事務所 修士 (工学)

*** 山口大学大学院理工学研究科 教授. 工博

**** 筑波大学システム情報系 助教・博士 (工学)

***** 山口大学大学院理工学研究科 助教 - 博士 (工学)

Lect., Graduate School of Science and Eng., Yamaguchi Univ., Dr.Eng.

Naito Architects, M.Eng.

Prof., Graduate School of Science and Eng., Yamaguchi Univ., Dr.Eng.

Assist. Prof., Faculty of Eng., Info. and Systems, Univ. of Tsukuba, Dr.Eng.

Assist. Prof., Graduate School of Science and Eng., Yamaguchi Univ., Dr.Eng.
} 


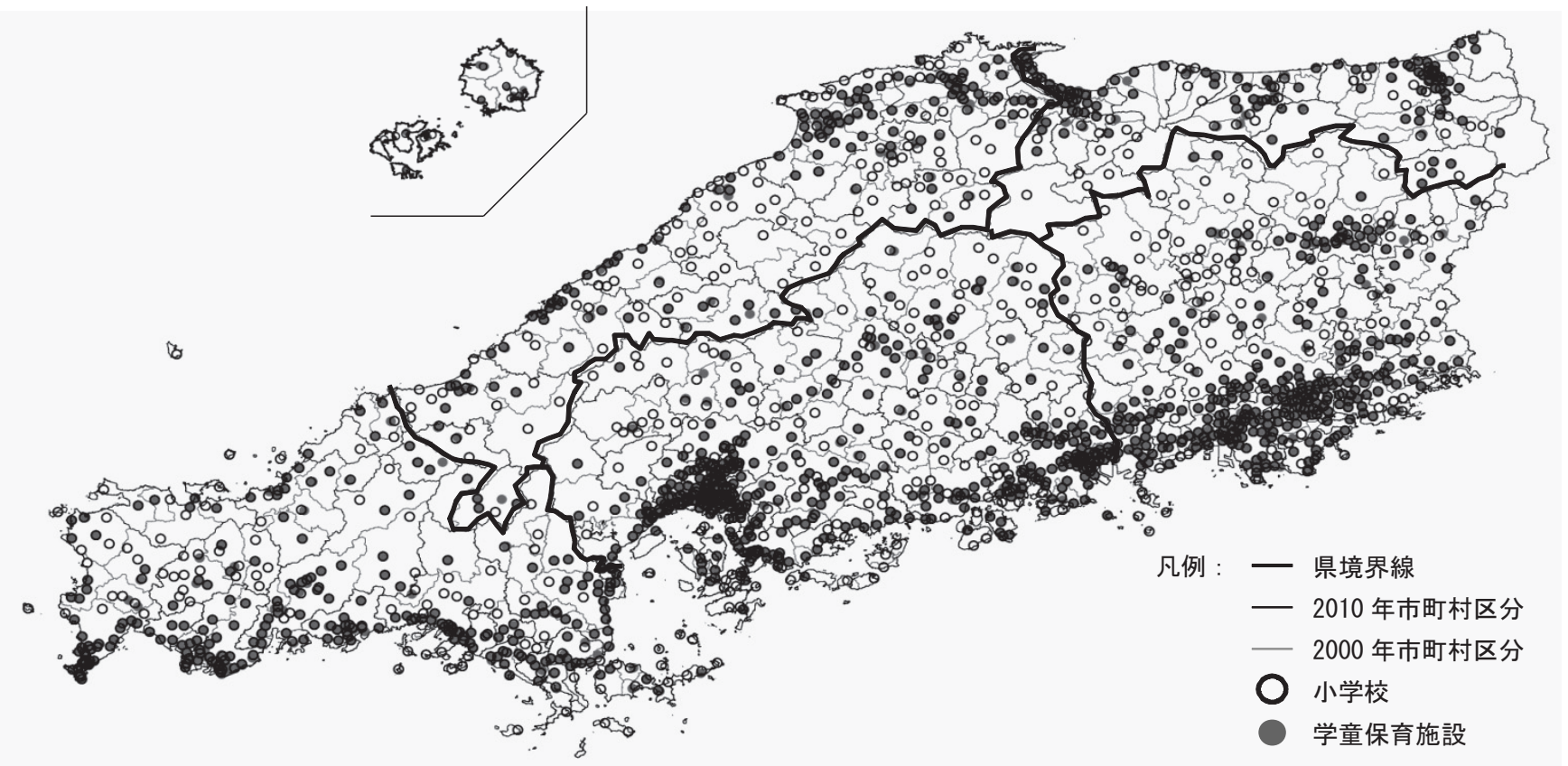

図 1 小学校及び学童保育施設の分布状況

表 2 設置タイプ分類と各県別構成比

表 1 中国地方 5 県の学童保育施設整備状況

\begin{tabular}{c|r|r|r|r|r|r}
\hline & $\begin{array}{c}\text { 2014年 } \\
\text { 自治体数 }\end{array}$ & $\begin{array}{c}\text { 2000自治体数 } \\
\text { 人口 }\end{array}$ & 小学校数 & 施設数 & $\begin{array}{c}2010 \text { 年 } \\
\text { 児童数 }\end{array}$ \\
\hline 鳥取県 & 19 & 39 & 588,667 & 142 & 136 & 31,544 \\
\hline 島根県 & 19 & 59 & 717,397 & 250 & 202 & 41,294 \\
\hline 岡山県 & 27 & 78 & $1,945,276$ & 423 & 370 & 109,380 \\
\hline 広島県 & 23 & 86 & $2,860,750$ & 565 & 524 & 162,907 \\
\hline 山口県 & 19 & 56 & $1,451,338$ & 344 & 325 & 75,517 \\
\hline 計 & 107 & 318 & $7,563,428$ & 1,724 & 1,557 & 420,642 \\
\hline
\end{tabular}

件により類型化を行い、地域類型と学童保育施設の設置率、施設設 置タイプ及び施設登録児童数の関係を明らかにするとともに、得ら れた知見を基に校区単位の施設利用児童数の推計を試み、今後の施 設拡充の地域的方向性を検討寸るための基礎資料を得ることを目的 とする。

\section{2. 調査概要}

本論では広域な地方圈全域における学童保育施設の整備状況と地 域格差を把握するため、中国地方 5 県全域を調査対象とする。分析 単位としては、平成の町村合併により都市地域の自治体が周辺の中 山間地域の自治体を吸収する形で広域合併した事例等が多いことか ら、より精緻に地域の実情を把握するため合併前の旧自治体（2000 年時点）を分析単位とした。分析に当たり各県の旧自治体別に以下 の資料を収集し統計解析を行った。(1)中国地方 5 県の各県別放課後 览童クラブ一覧 (2012 年) 注 4)、(2)中国地方 5 県の 2000 年市町村区分 図注 5)、(3)中国地方 5 県の旧自治体別小学校児童数 (1995 年・2010 年) 注 6)、(4)旧自治体別共働き世帯数 (2000 年) 注 7)、(5)旧市町村 (1950 年) 別農業地域類型一覧注8) である。また、山口県では各自治体の協 力が得られたことから、(6)山口県内各小学校学年別児童数 (1995 年・2010 年)、(7)山口県内各施設別学童保育施設登録児童数 (2010 年)、8山口県小学校区地図についても資料を収集し、山口県の校区 別情報を基に中国地方 5 県の校区単位の登録児童数の推計を行った。

\begin{tabular}{|c|c|c|c|c|c|c|c|}
\hline \multicolumn{2}{|c|}{ 設置タイプ } & 鳥取県 & 島根県 & 岡山県 & 広島県 & 山口県 & 中国地方 \\
\hline \multirow{2}{*}{ S型 } & $s$ 単一型 & $\begin{array}{c}61 \\
(43.0) \\
\end{array}$ & $\begin{array}{c}57 \\
(22.8) \\
\end{array}$ & $\begin{array}{c}198 \\
(46.8)\end{array}$ & $\begin{array}{c}255 \\
(45.1)\end{array}$ & $\begin{array}{c}122 \\
(35.5)\end{array}$ & $\begin{array}{c}693 \\
(40.2) \\
\end{array}$ \\
\hline & s複数型 & $\begin{array}{c}3 \\
(2.1) \\
\end{array}$ & $\begin{array}{c}6 \\
(2.4) \\
\end{array}$ & $\begin{array}{c}21 \\
(5.0) \\
\end{array}$ & $\begin{array}{c}50 \\
(8.8) \\
\end{array}$ & $\begin{array}{c}30 \\
(8.7) \\
\end{array}$ & $\begin{array}{r}110 \\
(6.4) \\
\end{array}$ \\
\hline \multirow{2}{*}{ O型 } & o単一型 & $\begin{array}{c}42 \\
(29.6) \\
\end{array}$ & $\begin{array}{c}71 \\
(28.4) \\
\end{array}$ & $\begin{array}{c}87 \\
(20.6) \\
\end{array}$ & $\begin{array}{c}104 \\
(18.4) \\
\end{array}$ & $\begin{array}{c}64 \\
(18.6) \\
\end{array}$ & $\begin{array}{c}368 \\
(21.3) \\
\end{array}$ \\
\hline & o複数型 & $\begin{array}{c}6 \\
(4.2) \\
\end{array}$ & $\begin{array}{c}9 \\
(3.6) \\
\end{array}$ & $\begin{array}{c}6 \\
(1.4) \\
\end{array}$ & $\begin{array}{c}9 \\
(1.6) \\
\end{array}$ & $\begin{array}{c}14 \\
(4.1) \\
\end{array}$ & $\begin{array}{c}44 \\
(2.6) \\
\end{array}$ \\
\hline \multirow{2}{*}{ S+O型 } & so2施設型 & $\begin{array}{c}1 \\
(0.7) \\
\end{array}$ & $\begin{array}{c}4 \\
(1.6) \\
\end{array}$ & $\begin{array}{c}4 \\
(0.7) \\
\end{array}$ & $\begin{array}{c}10 \\
(1.8) \\
\end{array}$ & $\begin{array}{c}18 \\
(5.2) \\
\end{array}$ & $\begin{array}{c}37 \\
(2.1) \\
\end{array}$ \\
\hline & so3-4施設型 & $\begin{array}{c}0 \\
(0.0) \\
\end{array}$ & $\begin{array}{c}6 \\
(2.4) \\
\end{array}$ & $\begin{array}{c}1 \\
(0.2) \\
\end{array}$ & $\begin{array}{c}2 \\
(0.4) \\
\end{array}$ & $\begin{array}{c}6 \\
(1.7) \\
\end{array}$ & $\begin{array}{c}15 \\
(0.9) \\
\end{array}$ \\
\hline \multicolumn{2}{|r|}{ N型 } & $\begin{array}{c}29 \\
(20.4) \\
\end{array}$ & $\begin{array}{c}97 \\
(38.8) \\
\end{array}$ & $\begin{array}{c}107 \\
(25.3)\end{array}$ & $\begin{array}{c}135 \\
(23.9)\end{array}$ & $\begin{array}{c}90 \\
(26.2)\end{array}$ & $\begin{array}{c}458 \\
(26.6)\end{array}$ \\
\hline \multicolumn{2}{|c|}{ Share型 } & 9 & 20 & 17 & 13 & 0 & 59 \\
\hline
\end{tabular}

凡例:

$\mathrm{s}$ 単一型…小学校敷地内に1施設の学童保育を実施している校区

s複数型…小学校敷地内に複数の学童保育を実施している校区

。単一型…小学校以外の他の施設(保育園、公民館等)で1施設の学童保育を 実施している校区

o複数型…小学校以外の他の施設で複数の学童保育を実施している校区

so2施設型…小学校、他の施設にそれぞれ1施設開設している校区 so3-4施設型…小学校、他の施設を使用し、3 4 施設開設している校区 $\mathrm{N}$ 型…学童保育が実施されていない校区

Share型…複数の校区を対象とした学童保育の対象となる校区

注)各県別の構成比は「Share型」を除いて算出した構成比である。

\section{3. 中国地方 5 県の学童保育施設整備状況と設置タイプ}

先ず中国地方 5 県の施設整備状況を表 1 、小学校及び学童保育施 設の分布を図 1 に示す。広島県が 524 施設と最も多く整備されてお り、次いで岡山県の 370 施設となっており、政令指定都市を有し瀬 戸内海に面する 2 県の施設数が多い状況である。逆に施設数が最も 少ないのは鳥取県の 136 施設で、次いで島根県の 202 施設となって おり、日本海側の 2 県の施設数が少ない。瀬戸内海と日本海、両方 に面する山口県は 325 施設で中間的値を示している。小学校数児童 数についても同様の傾向を示しており、各県の人口規模を反映する 值となっている。また、5 県全てで小学校数が施設数を上回ってい ることから、全県で学童保育施設の未整備校区が存在することが分 かる。分布図をみると瀬戸内海沿岸部を中心に小学校と学童保育施 設が分布している。日本海沿岸部では鳥取県、島根県の中心部に小 学校と学童保育施設の集積している地域を確認できるが、瀬戸内海 
沿岸部よりは分布密度は低い。各県共に内陸部に向かうにつれて分 布密度が低くなっており、学童保育施設が未整備な自治体も確認で きることから、学童保育施設の整備に地理的条件が大きく影響して

いることが考えられる。

次に各校区における学童保育施設の設置タイプを大きく学校内の みに設置される S 型、学校とその他の施設が併設される $\mathrm{S}+\mathrm{O}$ 型、そ の他の施設のみに設置される $\mathrm{O}$ 型、施設が未整備の $\mathrm{N}$ 型、複数の校 区を対象に施設が設置される Share 型の 5 タイプに分類し、1 校区 内に開設される施設数を反映させた計 8 タイプに細分類した。施設 設置タイプを各県別に集計した結果を表 2 に示す。中国地方では小 学校内に 1 施設を設置する $\mathrm{S}$ 単一型が 693 校区 $(40.2 \%)$ と最も多く、 小学校を中心に施設整備が進められているが、島根県では施設が設 置されている校区では $\mathrm{O}$ 単一型の校区が 71 校区 $(28.4 \%)$ と最も多く、 各県で設置タイプの構成比に差異が認められる。鳥取県では $\mathrm{S}$ 単一 型と $\mathrm{S}$ 複数型を含む $\mathrm{S}$ 型の設置タイプが 64 校区 $(45.1 \%)$ と最も多い が、同時に $\mathrm{O}$ 単一型と $\mathrm{O}$ 複数型を含む $\mathrm{O}$ 型の設置タイプも 48 校区 (33. $8 \%)$ 確認され、 5 県中で $\mathrm{O}$ 型の占める割合が最も高く、施設が未 整備の N 型が占める割合が $20.4 \%$ と 5 県で最も低い值を示すのが特 徵である。島根県でも $\mathrm{O}$ 型の校区が 80 校区 $(32 \%)$ と多いのが特徴で あるが、N型が 97 校区 $(38.8 \%)$ と最も高い割合で、校区をまたぐShare 型が 20 施設と 5 県で最も多いのが特徴といえる。岡山県と広島県の 設置タイプの構成比は類似しており、政令指定都市を有する両県で あるが中国山地の中山間地域を抱えるため $25 \%$ 前後の校区が施設未 整備の $\mathrm{N}$ 型となっている。山口県では、O型が占める割合は 20\%前 後で岡山県と広島県に近い值を示しているが、S 型の構成比は岡山 県と広島県よりも小さく、一方 $\mathrm{S}+\mathrm{O}$ 型が占める割合が高いのが特徴 である。

\section{4. 数量化正類とクラスター分析による旧自治体単位の地域類型}

中国地方は、瀬戸内海・日本海沿岸の都市地域だけでなく、沿岸 に点在する島嶼部、中国山地に沿って広がる中山間地域など、旧自 治体の地理的条件に大差がある。また、学童保育施設整備には地理 的条件以外にも、児童数や児童数の増減など対象となる児童に関す る情報を加味する必要がある。そのため、地理的条件と児童に関す る情報を用い、数量化而類とクラスター分析により旧自治体の地域

\begin{tabular}{|c|c|c|c|c|c|c|}
\hline \multicolumn{4}{|c|}{ カテゴリー } & \multirow[b]{2}{*}{$\begin{array}{l}\text { 自治 } \\
\text { 体数 }\end{array}$} & \multirow[b]{2}{*}{ 第1軸 } & \multirow[b]{2}{*}{ 第2軸 } \\
\hline $\begin{array}{c}\text { 地域条件 } \\
\text { 指標 }\end{array}$ & $\begin{array}{l}\text { スコア } \\
\text { 記号 }\end{array}$ & & テゴリー分類 & & & \\
\hline \multirow{4}{*}{$\begin{array}{l}\text { 廔業区 } \\
\text { 分類型 }\end{array}$} & 11 & \multicolumn{2}{|r|}{ 都市的地域 } & 44 & -2.04 & 1.28 \\
\hline & 12 & \multicolumn{2}{|r|}{ 平地農業地域 } & 21 & -0.88 & -0.89 \\
\hline & 13 & \multicolumn{2}{|c|}{ 中間農業地域 } & 120 & 0.03 & -1.14 \\
\hline & 14 & \multicolumn{2}{|c|}{ 山間農業地域 } & 129 & 0.87 & 0.73 \\
\hline \multirow{4}{*}{$\begin{array}{c}\text { 児童 } \\
\text { 維持率 } \\
(\%)\end{array}$} & 21 & \multicolumn{2}{|c|}{$77.1 \%$ 以上 } & 59 & -1.69 & 0.75 \\
\hline & 22 & \multicolumn{2}{|c|}{$62.1 \sim 77.0 \%$} & 91 & -0.29 & -1.12 \\
\hline & 23 & \multicolumn{2}{|c|}{$46.1 \sim 62.0 \%$} & 120 & 0.59 & -0.09 \\
\hline & 24 & \multicolumn{2}{|c|}{$0.0 \sim 46.0 \%$} & 48 & 1.15 & 1.14 \\
\hline \multirow{4}{*}{$\begin{array}{c}\text { 対象 } \\
\text { 児童数 } \\
\text { (人) }\end{array}$} & 31 & \multicolumn{2}{|c|}{90.1 人以上 } & 53 & -1.70 & 0.74 \\
\hline & 32 & \multicolumn{2}{|c|}{$61.1 \sim 90.0$ 人 } & 76 & -0.62 & -0.64 \\
\hline & 33 & \multicolumn{2}{|c|}{$30.1 \sim 30.0$ 人 } & 87 & 0.43 & -0.99 \\
\hline & 34 & \multicolumn{2}{|c|}{$0.0 \sim 30.0$ 人 } & 102 & 0.98 & 0.94 \\
\hline \multirow{4}{*}{$\begin{array}{l}\text { 児童 } \\
\text { 密度 } \\
\left(\text { ( } / \mathrm{km}^{2}\right)\end{array}$} & 41 & \multicolumn{2}{|c|}{31.1 人 $/ \mathrm{km}^{2}$ 以上 } & 26 & -2.38 & 2.05 \\
\hline & 42 & \multicolumn{2}{|c|}{$12.1 \sim 30.0 \mathrm{~N} / \mathrm{km}$} & 54 & -1.42 & -0.15 \\
\hline & 43 & \multicolumn{2}{|c|}{$4.1 \sim 12.0 \mathrm{~N} / \mathrm{km}$} & 107 & 0.10 & -1.53 \\
\hline & 44 & \multicolumn{2}{|c|}{$0.0 \sim 4.0 \mathrm{\Lambda} / \mathrm{km}^{2}$} & 131 & 0.97 & 0.91 \\
\hline 類 型 & & 1軸 & 第2軸 & & ログラ & \\
\hline 都市型 & -1 & .70 & 0.78 & & & \\
\hline 平地型 & & 77 & -0.29 & & & \\
\hline 中間型 & & 02 & -0.95 & & & \\
\hline 山間型a & & 49 & -0.05 & & & \\
\hline 山間型b & & 90 & 0.74 & & & \\
\hline
\end{tabular}

図 3 クラスター分析結果

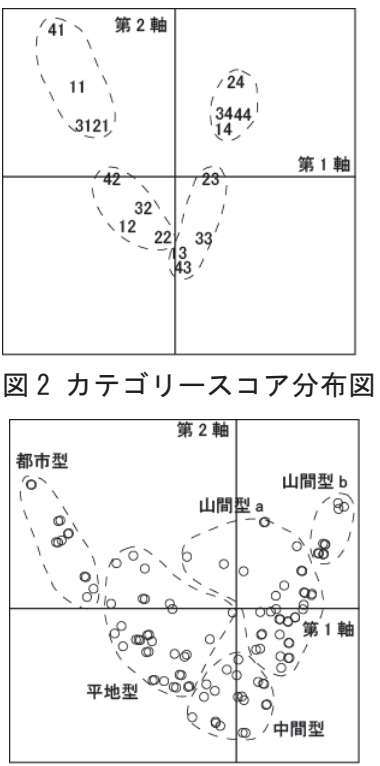

図 4 サンプルスコア分布図

表 4 各類型の地域条件

\begin{tabular}{|c|c|c|c|c|c|c|c|c|}
\hline \multirow[b]{2}{*}{ 類型 } & \multirow[b]{2}{*}{$\begin{array}{l}\text { 市町 } \\
\text { 村数 }\end{array}$} & \multicolumn{3}{|c|}{ 地域条件指標平均 } & \multicolumn{4}{|c|}{ 基礎データ平均 } \\
\hline & & $\begin{array}{c}\text { 児童 } \\
\text { 維持率 }\end{array}$ & $\begin{array}{c}\text { 対象 } \\
\text { 児童数 }\end{array}$ & $\begin{array}{l}\text { 児童 } \\
\text { 密度 }\end{array}$ & $\begin{array}{l}\text { 面皘竟 } \\
\left(\mathrm{km}^{2}\right)\end{array}$ & $\begin{array}{l}\text { 1995年 } \\
\text { 児童数 }\end{array}$ & $\begin{array}{l}\text { 2010年 } \\
\text { 児童数 }\end{array}$ & $\begin{array}{l}\text { 共働き } \\
\text { 世帯率 }\end{array}$ \\
\hline 都市型 & 39 & 84.8 & 120.8 & 56.2 & 131.6 & 9961.9 & 7212.4 & 65.7 \\
\hline 平地型 & 54 & 74.5 & 112.7 & 19.3 & 75.2 & 1882.5 & 1349.8 & 74.6 \\
\hline 中間型 & 64 & 66.6 & 52.1 & 7.1 & 90.6 & 1005.5 & 584.4 & 78.6 \\
\hline 山間型a & 93 & 56.8 & 39.6 & 3.0 & 94.9 & 449.8 & 215.3 & 83.0 \\
\hline 山間型b & 68 & 46.9 & 21.1 & 1.3 & 118.9 & 317.4 & 133.0 & 83.4 \\
\hline
\end{tabular}

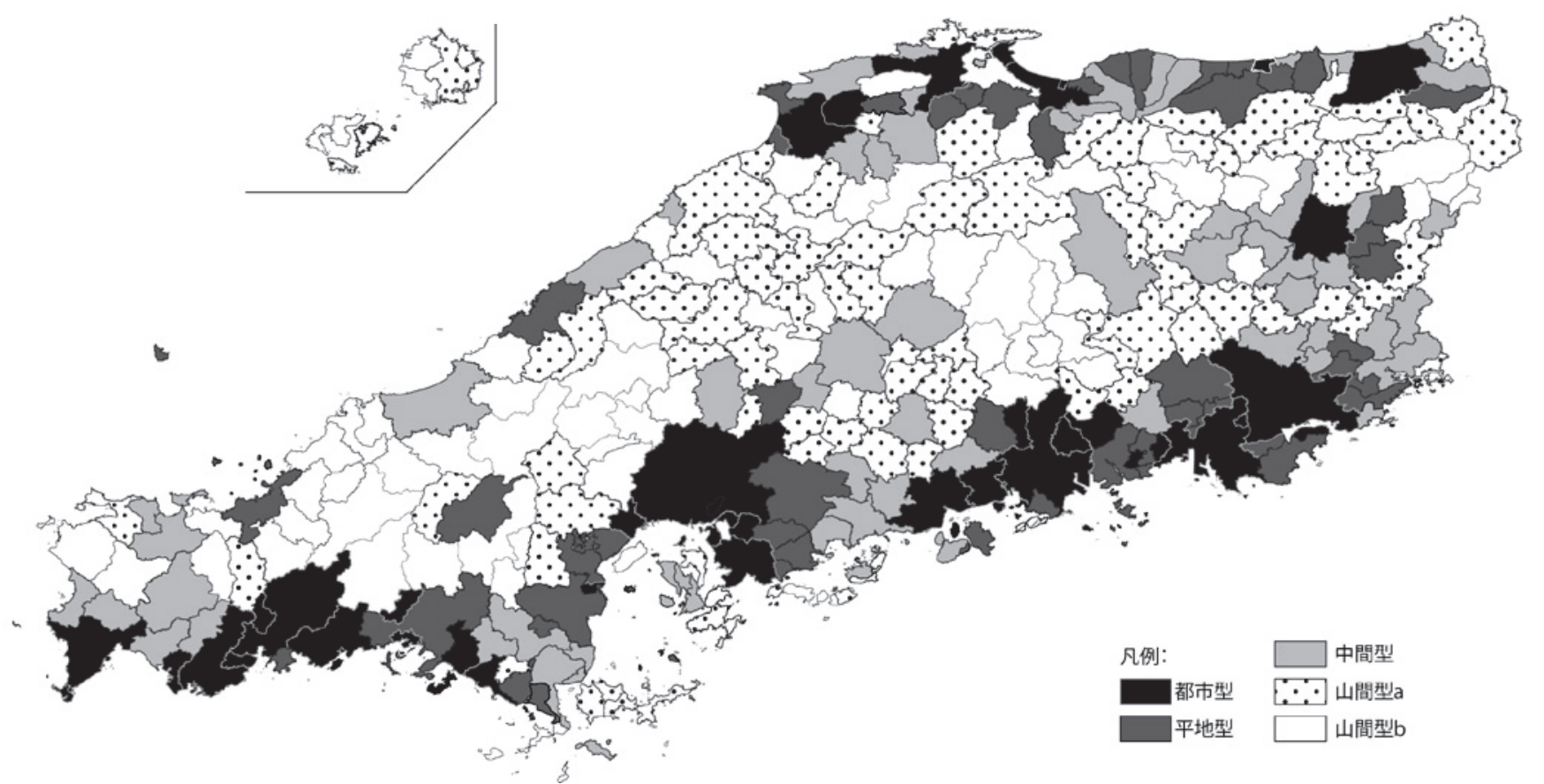

図 5 地域類型分布図 
条件の類型化を行う。数量化正類分析に用いた指標は以下の通りで ある。(1)農業地域類型：1950 年時点の自治体毎に設定されており、 分析単位となる 2000 年時点の自治体では複数の農業地域類型が含 まれる自治体もある。この場合は最も面積割合が大きい農業地域類 型を適用した。(2)児童維持率 $(\%)=2010$ 年児童数/1995 年児童数 $\times$ 100 : 学童保育が児童福祉法に位置づけられた 1997 年に近い 1995 年の児童数を 100 とした場合の 2010 年児童数の割合である。(3)対象 児童数 $($ 人 $)=2010$ 年児童数 $\times$ 共働き世帯率 $\times 0.5$ (人)：旧自治体単 位の小学校児童数に共働き世帯率を乗じ、学童保育の中心となる 3 年生までの児童数を算出するため一律に 0.5 を乗じた。(4)児童密度 $(人 / \mathrm{km} 2)=2010$ 年児童数/旧自治体面積: 都市地域と中山間地域の 児童密度を考慮するため指標に設定する。

カテゴリー区分一覧を表 3、カテゴリースコア分布を図 2 に示す。

第 1 軸は十側に山間的特長を示すカテゴリー、一側に都市的特長を 示寸カテゴリーが位置しており、旧自治体の都市・山間地域の特性 を示す軸として解釈できる。第 2 軸は十側に各カテゴリーの最大・ 最小值が位置し、一側に中位の值が位置することから、平地・中間 地域の特徵を示す軸として解勫できる。次に第 $1 \cdot 2$ 軸のサンプルス コアを用いクラスター分析 (ward 法)を行い旧自治体の類型化を行 った。デンドログラムを図 3、サンプルスコアを図 4 に示す。地域 条件の特徴より、「都市型」39 自治体、「平地型」54 自治体、「中間 型」64 自治体、「山間型 a」93 自治体、「山間型 b」68 自治体の 5 類 型に区分された。各地域の特徴を検討するため、各類型の地域条件 を表 4、地域類型分布を図 5 に示寸。

「都市型」は児童密度が 56.2 人 $/ \mathrm{km} 2$ と高く、対象児童数 $(120.8$ 人) が 5 類型中最も多い。児童維持率も $84.8 \%$ と児童の減少が最も少な く、各県の中心都市を有する旧自治体がこの類型に属している。「平 地型」は「都市型」周辺部に位置する旧自治体が多く、览童密度は 19.3 人 $/ \mathrm{km} 2$ に低下しているが、対象児童数 (112.7 人)は「都市型」に 次いで多く、児童維持率も $74.5 \%$ と一定の児童数を維持している。 「中間型」は「平地型」と「山間型」の中間に位置する旧自治体であり、 览童密度は 7.1 人 $/ \mathrm{km} 2$ と「平地型」よりも半数以下と低いのが特徴で、 対象児童数 $(52.1$ 人) も少なくなり、児童維持率は $66.6 \%$ と児童の減 少が大きい。「山間型 a」は内陸部の山間地域に位置する旧自治体で、 児童密度は 3.0 人 $/ \mathrm{km} 2$ と低いのが特徴であり、対象児童数 ( 39.6 人) も少なく、学童保育 1 施設の夕で旧自治体の児童に対応できる数で ある。児童維持率は $56.8 \%$ と児童数の減少も著しい。「山間型 b」は 「山間型 $\mathrm{a} 」 と$ 同様内陸部の山間地域に位置する旧自治体であるが、 览童密度は 1.3 人 $/ \mathrm{km} 2$ 、対象児童数は 21.1 人、児童維持率は $46.9 \%$ で、「山間型 a」よりもさらに過疎化・少子化が進行する過疎地域と して位置付けられる。

\section{5. 地域類型と施設整備状況}

\section{5-1. 地域類型と自治体平均設置率}

学童保育を推進する全国組織である全国学童保育連絡協議会では、 設置率 $(\%)=$ 学童保育施設数/小学校数 $\times 100$ と定義し、学童保育施 設の整備水準を評価している。そこで本論では、旧自治体毎に学童 保育施設数と小学校数を集計し、各自治体の学童保育施設設置率を 算出し地域類型との関係を論考する。各類型に属する自治体数、平 均小学校数、平均施設数、自治体平均設置率を表 5 に示す。尚、表

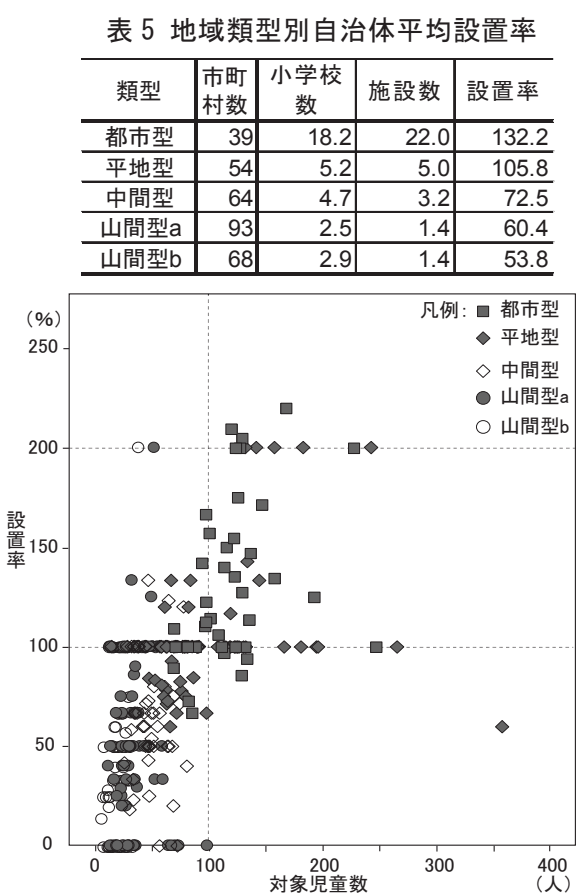

図 6 自治体設置率と対象児童数

5 の自治体設置率は、自治体単位で算出した設置率を合計し旧自治 体数で除した值のため、平均施設数と平均小学校数から求められる 設置率とは異なる値となる。

対象児童数の多い「都市型」では平均小学校数が 18.2 校、平均施 設数が 22.0 施設となり、施設数が小学校数を上回るため、自治体平 均設置率も $132.2 \%$ と 100\%を超える值となった。「平地型」について も、「都市型」と比較すると平均小学校数が 5.2 校と、旧自治体内の 小学校数は大幅に減少するが、平均施設数は 5.0 施設で、自治体平 均設置率は $105.8 \%$ となり、「都市型」の旧自治体と同様に平均設置 率は $100 \%$ を超える。しかし、学童保育施設を複数開設する校区が 存在しているため、自治体平均設置率が 100\%を超える「都市型」・ 「平地型」の旧自治体においても学童保育施設の未整備校区が存在 している点は留意すべきである。「中間型」では、平均小学校数は 4.7 校で「平地型」と近い值を示寸が、平均施設数は 3.2 施設で、 自治体平均設置率は $72.5 \%$ と $100 \%$ を切る状況となり、「山間型 a」 (60.4\%)、「山間型 b」（53.8\%）となるに従い自治体平均設置率も低 下している。このように地域条件と自治体平均設置率の間には明確 な関係性が示され、児童数の多い都市地域ほど施設整備が進んでい るが、児童数の少ない山間地域ほど施設整備が遅れている状況を示 している注9)。

\section{5-2. 地域類型別自治体設置率と対象児童数}

地域類型別自治体設置率と対象児童数の関係を図 6 に示す。学童 保育施設の整備プロセスとしては、小学校区を単位に学童保育施設 1 施設が整備され、その後、対象児童数の増加に伴う施設の過密化 が考慮され、施設増設が検討されることが一般的である。従って設 置率 100\%の線上に「都市型」から「山間型 b」までの調査対象とな った旧自治体のおよそ $1 / 3$ にあたる 110 自治体が分布した。校区単 位の対象児童数は 130 人以下が大多数であるが、中には対象児童数 が 200 人を超える旧自治体も散見される。自治体設置率 $100 \%$ 以下の 旧自治体の多くが対象児童数 100 人以下で、「中間型」「山間型a」、 「山間型 b」の自治体が多いが、100\%に近くなると「都市型」「平 


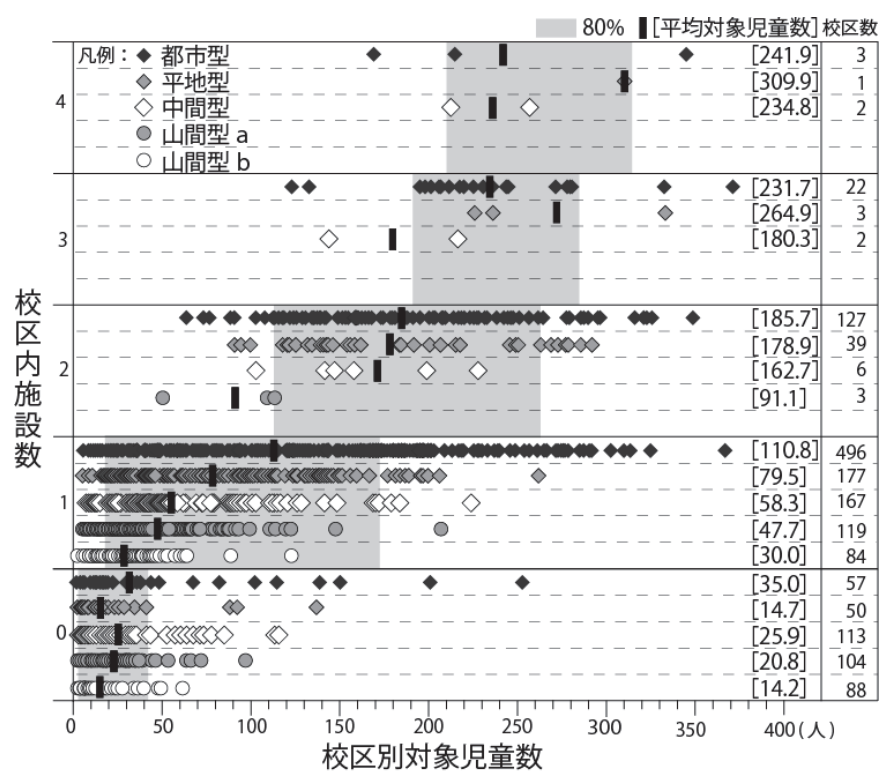

図 7 校区内施設数と対象児童数

地型」の旧自治体の分布も見られる。逆に設置率 $100 \%$ 超える旧自 治体の多くは対象児童数が 100 人以上で「都市型」・平地型」に区 分される旧自治体が多くなる。設置率 $200 \%$ 以上の旧自治体の多くは 町村規模の自治体で、旧自治体内の小学校数が 1 校から 2 校のもの がほとんどである。人口 5 万人以上の市規模の人口を有し、設置率 $200 \%$ を超える旧自治体は広島県府中町、山口県宇部市、島根県松江 市の 3 自治体のみであった。全体的傾向として、対象児童数が増加 するほど設置率が高くなる傾向が認められた。

\section{5-3. 地域類型別校区単位の設置率と対象児童数}

次に校区を単位とした整備状況を把握するため、校区内施設数と 対象児童数の関係を図 7 に示す。地域類型は旧自治体で行った地域 類型をそのまま適用し、旧自治体内にある小学校区は全て旧自治体 の地域類型とし集計を行った。

校区内施設数 0 の校区とは学童保育施設が未設置の校区で、平均 対象児童数は「都市型」の 35.0 人が最大值となり、全類型で平均対 象児童数は 50 人以下である。対象児童数が少ないことが施設未設置 の大きな理由と考えられるが、対象児童数が 100 人を超えているに もかかわらず施設未設置の校区が散見される。校区内施設数 1 の校 区における対象児童数の幅は大きい。これは、一般的な施設設置が 校区を単位として行われ、1 校区に 1 施設から施設整備が開始され る場合が多いからである。平均対象児童数は「都市型」が 110.8 人 と 100 人を超えているが山間地域ほど平均対象児童数は減少し、「山 間型 b」では 30.0 人である。「都市型」を中心に対象児童数が 200 人を超えているにもかかわらず施設数 1 の校区が相当数存在するが、 これらの校区では施設における览童の過密化が問題となっている可 能性が考えられる。

校区内施設数 2 の校区は対象児童数が 100 人から 300 人の校区が 大多数を占め、平均対象児童数は「都市型」 185.7 人、「平地型」 178.9 人、「中間型」 162.7 人、「山間型 $\mathrm{a} 」 91.1$ 人で、「山間型 $\mathrm{a} 」 を$ 除く と施設数 1 の校区より約 100 人対象児童数が増加している。校区内 施設数 3 の校区は対象児童数が 200 人から 350 人の校区が大多数を 占め、「都市型」に分類される校区が多数で、平均対象児童数も施設 数 2 の校区と比較するとさらに 50〜80人程度増加している。校区

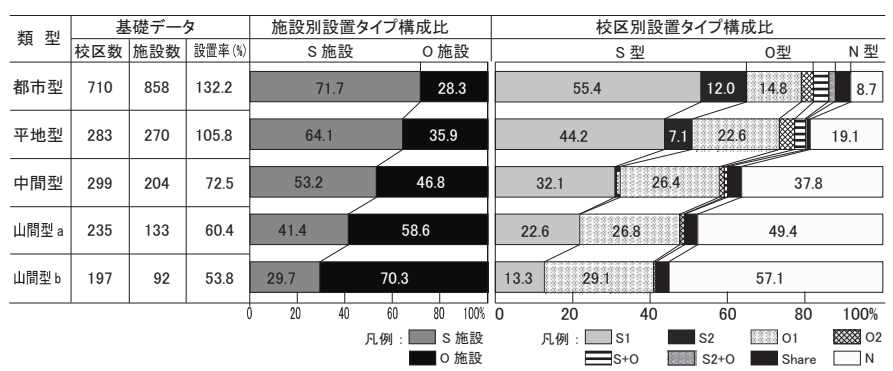

図 8 地域類型と設置タイプ

内施設数 4 の校区はサンプルが少なく、「都市型」に 3 校区、「平地 型」に 1 校区、「中間型」に 2 校区存在するが、対象児童数は施設数 3 の校区より多少多い程度である。

以上、地域類型と校区内施設数には明瞭な関係性が認められ、「都 市型」・「平地型」校区では児童数に対応し施設の増設が行われるが、 「中間型」、「山間型 $\mathrm{a} 」$ 、「山間型 b」では大半が 1 校区 1 施設か未整 備校区であり、校区単位で見ても地域間格差が大きい実態が示され た。

\section{5-4. 地域類型別校区単位の設置タイプ}

地域類型別の校区単位の設置タイプを図 8 に示す。「都市型」に属 する学童保育施設 858 施設の約 7 割は小学校敷地内に開設される「S 型施設」で、他の約 3 割は小学校敷地外に開設される「O型施設」 となる。校区別設置タイプは「S 単一型」が $55.4 \%$ と最も多く、次い で「O単一型」が $14.8 \%$ 、校区内に 1 施設開設されるタイプが約 7 割を占めるが、「S 複数型」等の校区内に複数開設されるタイプを合 計すると $21.1 \%$ 占める。「N 型」の校区は $8.7 \%$ と少ないが、それで も 1 割弱の未設置校区が存在する。「平地型」に属する 283 施設の 64. $1 \%$ が「S 型施設」で $35.9 \%$ が「O型施設」となり、「都市型」より も「O型施設」の占める割合が高い。校区内で 1 施設開設される夕 イプは 66. 8\%で「都市型」と比較しても大きな差異は見られないが、 校区内で複数開設されるタイプは $14.1 \%$ と少なくなり、未設置校区 の「N型」が 19.1\%と大幅に増加する。

「中間型」は「O型施設」が更に増加し、53.2\%が「S 型施設」、 46. $8 \%$ が「O型施設」の割合となり、 $\mathrm{S}$ 型と $\mathrm{O}$ 型の施設割合が半々と なる。複数開設される校区割合の合計も $3.7 \%$ と大幅に減少し、未設

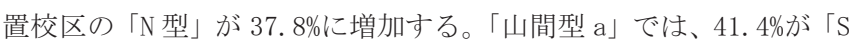
型施設」で $58.6 \%$ が「O型施設」となり、小学校敷地外で開設され る施設の方が多くなる注 10)。校区別設置タイプでは「中間型」より も更に「N 型」の未設置校区が増加し約半数の校区で施設が未整備 の状況である。「山間型 b」ではこの傾向は更に強まり、施設設置校 区では「O型施設」が 7 割を超え、「N型」が約 6 割近くと半数以上 の校区で施設が未整備の状況である。

以上より、都市地域ほど未設置校区の割合が少なく小学校敷地内 を中心に施設整備が進み、山間地域ほど未設置校区の割合が高く、 施設整備が行われる場合も小学校敷地外で開設される場合が多いと いう地域的特徵が認められる。

\section{6. 施設登録児童数の推計}

学童保育施設の整備状況は、1 校区に 1 施設以上の施設整備が進 むが、対象児童数が多く施設の大規模化・過密化が問題の中心とな 
表 6 山口県の校区別の利用率中央值と整合率

\begin{tabular}{|c|c|c|c|c|c|c|}
\hline \multicolumn{2}{|l|}{ 類型 } & 対象児童数 & 校区数 & 利用率中央値 & 整合数 & 整合率 \\
\hline \multirow{3}{*}{ 都市型 } & $\mathrm{A}$ & $0-40$ & 16 & 60.88 & 7 & 43.8 \\
\hline & $\mathrm{B}$ & $40.1-130$ & 49 & 47.45 & 29 & 59.2 \\
\hline & $\mathrm{C}$ & 130.1以上 & 50 & 39.36 & 35 & 70.0 \\
\hline \multicolumn{3}{|c|}{ 都市型計 } & 115 & 41.97 & 71 & 61.7 \\
\hline \multirow{3}{*}{ 平地型 } & & $0-30$ & 8 & 63.03 & 3 & 37.5 \\
\hline & $B$ & $30.1-120$ & 20 & 51.67 & 15 & 75.0 \\
\hline & $\mathrm{C}$ & 120.1 以上 & 18 & 44.26 & 18 & 100.0 \\
\hline \multicolumn{3}{|c|}{ 平地型計 } & 46 & 49.58 & 36 & 78.3 \\
\hline \multirow{3}{*}{ 中間型 } & $\mathrm{A}$ & $0-22$ & 15 & 80.91 & 8 & 53.3 \\
\hline & $B$ & $22.1-80$ & 16 & 45.74 & 8 & 50.0 \\
\hline & $\mathrm{C}$ & 80.1 以上 & 14 & 40.30 & 10 & 71.4 \\
\hline \multicolumn{3}{|c|}{ 中間型計 } & 45 & 47.87 & 26 & 57.8 \\
\hline \multirow{3}{*}{$\begin{array}{l}\text { 山間型a } \\
\text { 山間型b }\end{array}$} & $\mathrm{A}$ & $0-12$ & 6 & 160.60 & 4 & 66.7 \\
\hline & B & $12.1-41$ & 23 & 61.08 & 16 & 69.6 \\
\hline & $\mathrm{C}$ & 41.1以上 & 13 & 38.18 & 9 & 69.2 \\
\hline \multicolumn{3}{|c|}{ 山間型計 } & 42 & 54.70 & 29 & 69.0 \\
\hline \multicolumn{3}{|c|}{ 山口県全体 } & 248 & 47.56 & 162 & 65.3 \\
\hline
\end{tabular}

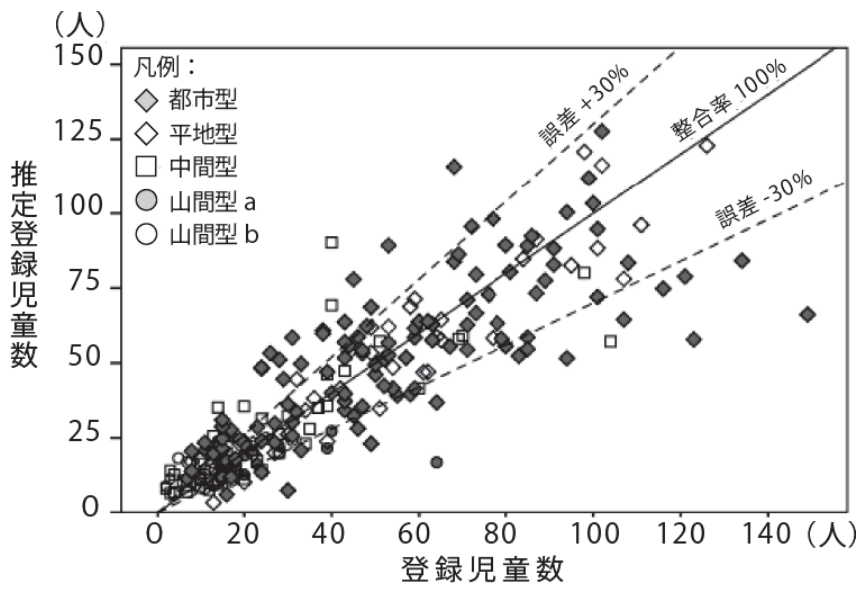

図 9 山口県の校区別の推定登録児童数と登録児童数

る「都市型」、共働き世帯率は高いが児童数が少なく施設の未整備が 問題の中心となる「山間型 b」等、地域間格差が大きく施設整備上 の検討課題も異なるものと考えられる。そこで、地域類型と施設利 用人数の関係を検討寸るため、試論として各校区を対象に 1 施設の 登録児童数の推計を行う。

6-1. 山口県における登録児童数の推計と推計値の整合率

山口県では全 325 施設の登録児童数が調査可能であったため、 2011 年 5 月時点の校区別の利用率 (校区の各施設の登録児童数の和/ 校区の対象児童数) を算出し、各地域類型の校区を対象児童数により A 群、B 群、C 群の 3 グループに区分し注 ${ }^{11)}$ 、「都市型」から「山間型」 までの計 12 種の校区別の利用率中央值を算出した。得られた校区別 の利用率中央值を校区の対象児童数に乗じ校区内の施設数で除する ことにより校区単位の 1 施設あたりの推定登録児童数を算出した。 実際の施設の登録児童数と推定登録児童数を比較し、誤差が $30 \%$ 未 満内の校区数を整合数に数え、その割合を整合率と表記する。表 6 に山口県の校区別の利用率中央值と整合率、図 9 に山口県における 校区別の 1 施設あたりの推定登録児童数と実際の登録児童数の関係 を示す。各類型で対象児童数の少ない $\mathrm{A}$ 群の利用率が他より高くな った。学童保育施設の対象児童は小学校 3 年までの低学年児童が中 心となるが、児童数の少ない校区では高学年児童も受け入れている 施設が存在するためと考えられる。そのため A 群では利用率に幅が
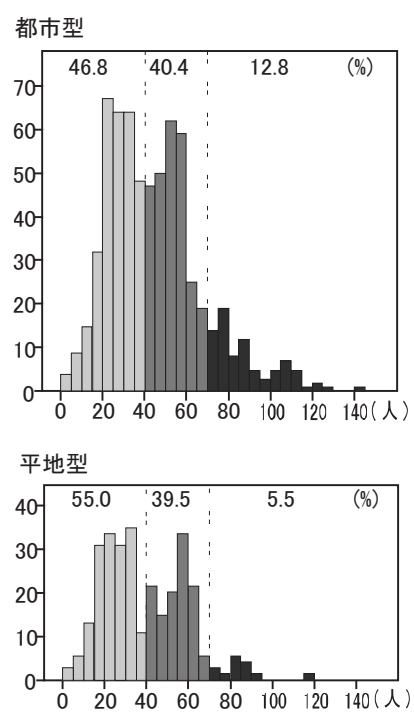

凡例 : [DIM] $X$ : 登録児童数 $Y$ :校区数
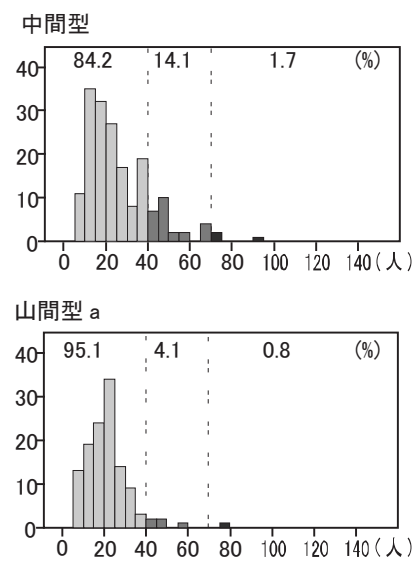

山間型 b

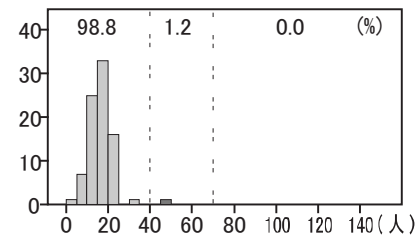

図 10 中国地方の校区単位の 1 施設あたりの推定登録児童数

あり整合率は低い。中位グループの B 群では A 群よりも「都市型」、

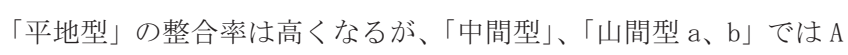
群とほぼ同じ整合率となっている。対象児童数の多いC 群では全類 型で約 $70 \%$ 整合率が得られた。全体では、学童保育を有する山口 県の 248 校区のうち 162 校区 $(65.3 \%)$ が実際の登録児童数と推定し た登録児童数の誤差が $30 \%$ 未満に収まる結果となった。

\section{6-2. 中国地方の校区単位の施設登録児童数の推計}

中国地方 5 県の学童保育施設が開設されている全校区を地域類型 別に対象児童数より A 群、B 群、C 群に区分し、山口県のデータから 得られた各 12 種の利用率中央值をそれぞれ乗じ、校区内の施設数で 除することにより校区単位の 1 施設あたりの登録児童数を推計した 注12)。得られた結果を図 10 に示す。

「都市型」では、1 施設あたりの推定登録児童数がガイドライン推 奨基準である 70 人を超える校区が $12.8 \%$ 、40-70人とガイドライン 推奨基準は満たすが新たに定められた設置基準 40 人以下を満たさ ない校区が $40.4 \%$ 占めており、半数以上の校区において新設置基 準を満足しないため、校区内における施設増設がこれら地域の課題 となる。「平地型」では、ガイドライン推奨基準を超える校区が $5.5 \%$ で「都市型」と比較すると大幅に低減する。ガイドライン推奨基準 は満たすが新設置基準を満たさない 40-70人の校区は約 $40 \%$ と「都 市型」とほぼ同じ割合であるが、新設置基準を満たす 40 人以下の校 区が $55.0 \%$ と半数を超える。従って、「都市型」、「平地型」に分類さ れる校区では 1 施設 40 人以下という新設置基準を満たすため、校区 内における施設増設が主要な課題となる。

一方、「中間型」では、84. $2 \%$ の校区で推定登録児童数は 40 人以下 となり、施設の大多数で新設置基準を満たし、ガイドライン推奨基 準を超える 70 人以上の校区も $1.7 \%$ しか存在しない。「山間型a」、山山 間型 b」と山間地域に行くほど推定登録児童数は減少するため、「山 間型 a」の校区で 95.1\%、「山間型 b」では 98.8\%が新設置基準の 40 人以下を満たす結果なった注 ${ }^{13)}$ 。従ってこれらの地域では 1 施設当 
たりの利用人数に関する新設置基準はほぼ満足されているものの、 未整備校区が多いため、対象児童数が少ない中で未整備校区の解消 方法を検討することが主要な課題となる。

\section{7. 結論}

本論では、中国地方 5 県を対象に旧自治体を単位に地域類型を行 い学童保育施設整備状況の地域性を明らかにし、校区単位の登録 児童数の推計を試みた。得られた知見は以下の通りである。

1) 児童数の多い都市地域 (都市型+平地型) の自治体平均設置率は 100\%を超え、旧自治体内の学童保育施設整備はある程度進んでい るが、中間地域 (中間型)では平均設置率は約 7 割に止まり、山間 地域 (山間型 $\mathrm{a}+\mathrm{b}$ ) ではさらに 6 割を下回る結果となり、旧自体単 位に見ると地域間格差が顐著に認められる。

2) 学童保育施設の一般的整備プロセスでは、小学校区を単位に 1 校 区に対し学童保育施設 1 施設が整備され、その後、対象児童数の 増加による施設の過密化が考慮され施設増設が検討される。その ため「都市型」から「山間型 b」までの自治体の約 $1 / 3$ にあたる 110 自治体が設置率 $100 \%$ であった。対象児童数が少ないほど設置 率は低く、「中間型」、「山間型 a」、「山間型 b」に属する自治体が 多く、逆に対象児童数が多いほど設置率は高くなり、「都市型」、 「平地型」に属する自治体が多くなる傾向が認められた。

3) 地域類型と校区内施設数の間には明瞭な関係性が認められ、「都市 型」・平地型」校区では児童数に対応し施設の増設が行われるが、

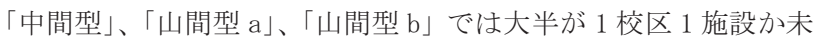
整備校区であり、地域間格差が大きい実態が示された。

4) 地域類型と設置タイプの間にも明瞭な関係性が確認され、都市地 域ほど小学校敷地内で施設整備される割合が高く、中間地域、山 間地域になるほど小学校敷地外で施設整備される割合が高くなり、 かつ施設未整備校区の割合が高くなる。

5) 山口県のデータを基に中国地方 5 県の各校区を対象に 1 施設の推 定登録児童数を推計し、都市地域では約半数の校区が 1 施設 40 人 以下という新設置基準を満たさず、逆に中間地域、山間地域では 大半の校区で新設置基準を満たすことを示した。

以上より、国民生活センターの調查報告でも指摘されているが、 本論でも学童保育施設の整備状況に大きな地域間格差があることが 明らかとなった。都市地域では、既に一定の施設整備は進んでおり、 施設の過密化を解消し新設置基準を満たすための施設増設策が今後 の検討課題と位置づけられる。具体的には、都市地域では学校内敷 地での $\mathrm{S}$ 型専用施設の整備手法と学校外敷地での $\mathrm{O}$ 型施設の拡充策 が重要になってくると考える。全国学童保育連絡協議会が実施し公 表した調查 ${ }^{1)}$ によると、空き教室を利用した学童保育施設の施設平 均床面積、児童一人当たりの面積は他の施設を利用した施設と比較 すると狭いにもかかわらず、施設開設の容易さからか空き教室を活 用した施設が最も増加していることが指摘されている注 ${ }^{14)}$ 。都市地 域では S 型施設を中心に施設整備が進んでいるが、児童維持率も高 い值を示していることより空き教室の発生が抑制され、いずれ空き 教室を活用した施設整備策に限界が来ることが予想される。空き教 室の活用を中心とした現状の施設拡充策だけではなく、連絡協議会 が求める「生活の場」にふさわしい質を有した施設建築計画と施設 配置計画が求められる。
一方、中間地域と山間地域では、対象児童数が少ない中で未整備 校区を解消するための施設整備手法と施設運営方式が主要な検討課 題となる。具体的には、本論では自治体と校区単位で分析を行った ため分析対象とならなかった校区や自治体を跨いだ Share 型施設の 整備手法と児童が安全に施設へアクセス寸るための交通政策が重要 になってくると考える。本論より中間地域と山間地域では都市地域 よりも共㗢き世帯率が高いことが明らかになっており、学童保育施 設への潜在的ニーズは高いが、施設運営の補助金交付要件を満たす だけの児童数がいないため開設にいたっていない校区注 ${ }^{9)}$ が多数存 在する。隣接する $N$ 型校区が集まり補助金交付要件を満たした上で Share 型施設を整備することは未整備校区と地域間格差の解消の有 効な手段となり得る。しかし、山間地域では旧自治体で 1 校区のよ うな地域もあり、隣接する $\mathrm{N}$ 型校区が集まった場合、現行政区域を 跨ぎ、対象となる地域が広域となることが考えられる。そのため Share 型の施設整備手法だけではなく、同時に児童が安全に施設へ アクセス寸るための交通手段を検討しておく必要がある。また、推 計值によると中間地域と山間地域は 1 施設 40 人以下という新設置基 準を満たす割合が高いため、施設計画そのものよりは対象となる複 数の校区内のどこに施設を配置するかという施設配置計画がより重 要な検討課題になる。施設配置計画を検討する際、校区間、行政区 域を跨ぐ場合は自治体間で施設立地による利害関係の対立が生じる 可能性が高い。校区間のみの場合は市町村、行政区域を跨ぐ場合は 都道府県や国などのように、より広域の取り組みを行う行政が中立 的立場で積極的に関与し当事者間の利害関係を調整すると同時に、 施設への交通手段などについても積極的な支援を行う必要がある。 地域間格差の解消と広域的な施設拡充を行うためには国や都道府県 と市町村との連携は不可欠であると考えられる。本論で示したデー タや知見は、広域的な取り組みを行う国や都道府県と市区町村の連 携を促すための有用な基礎資料になるものと考える。

\section{謝辞}

本研究は日本学術振興会科学研究費 $(25289210)$ の助成を受けたも のである。

注

注1）文献1参照

注2）厚生労働省雇用均等・児童家庭局長より「放課後児童クラブガイドライ ンについて」というタイトルで自治体首長宛に平成19年10月に出された通 知である。このガイドラインにより、対象児童、規模、設備などに関し14 項目の基準が示されており、対象児童については「小学校 $1 \sim 3$ 年」、規模に ついては「40人程度までが望ましく、最大 70 人まで」と記載されている。

注3）子ども・子育て関連3法の成立に伴い平成 26 年6月に児童福祉法が一部改 正され、学童保育施設の設置基準が定められ、規模については「支援の単 位を構成する児童の数はおおむ衫 40 人以下」、対象児童については「小学校 1〜 6年」、施設面積については「 1 人当たり施設面積を $1.65 \mathrm{~m}^{2}$ 以上」などが 規定されており、ガイドライン推奨基準よりも高い整備基準を示している。

注4）各県各市のHP、各県の健康福祉部、教育委員会、子ども未来課などの学 童保育施設担当部署に問い合わせを行い、クラブ名称、対象校区、開設場 所、所在地の情報を収集した。

注5）国土交通省国土政策局国土数值情報より情報を収集した。

注6）該当年度の文部科学省学校基本調査より情報を収集した。

注7) 国勢調查(2000年) より6歳から12歳児童を持つ世帯数と夫婦共に就労し ている世帯数より計算により求めた。

注8）農林水産省1950年自治体区分別農業地域類型一覧より情報を収集した。 
注 9）山口県内の学童保育未実施自治体へのアンケートによれば、学童保育 は「放課後児童健全育成事業費補助金」制度により国から $2 / 3$ の補助を受 けるが、補助金交付要件 (利用児童が 1 日の来所児童数の月平均が 10 人以 上いること）を満たせないため実施に至れないケースが 62 校区と最も多く、 児童数が少ない小規模校では放課後子ども教室を実施し対応しているため、 学童保育は実施していない(長門市 5 校区) という回答も得られた。

注 10）山口県内の山間型校区のO型施設設置自治体への聞取り (16 事例)に

よれば、空き教室が存在せず開設できる施設を模索し実施 (10 事例)、学童 保育実施当初、小学校で受け入れておらず、運営を委託する社協や教育委 員会所在地で学童保育を開始 (3 事例) 、学校隣接地に使用可能な建物 (元保 育園、元児童館等) があり、隣接地を使用 (6 事例) という回答を得た。

注11）各類型をA群、B群、C群の3グループに区分する際、対象児童数が近い 值となる「都市型」と「平地型」で異なる人数区分を採用した理由は、該 当する校区数を一定数確保できるように調整したためである（例えば、平 地型の人数区分を都市型に適用した場合、A群は9校区となり都市型校区数 115 校区の $10 \%$ 以下の校区数となる)。ここで得られた利用率中央值を推計に 用いるため、各郡に対象校区の $10 \%$ 以上の校区が該当するよう調整する必要 があると判断した。また、「山間型a」と「山間型b」を山間型として合算し た理由は、山口県では山間型aに分類される校区は14校区のみであり、「山 間型a」単独で利用率中央值や整合率などを求めるには母数となる校区数が 少ないと判断したためである。

注12）本研究を実施している研究グループでは、山口県を含む中国地方の一 部地域において実際の登録児童数に各施設の施設面積を加味し、現状の施 設の人数規模と面積規模両面より新設置基準の適合状況を調査し、その結 果を学会発表している ${ }^{10)}$ 。今後も実数值をべースとした調査を拡大する予 定であるが、中国地方の学童保育施設を取り巻く全体像を概観する必要が あると考えたため、山口県で得られたデータをもとに中国地方全域の推計 を行った。推計の精度に一定の限界はあると考えるが、山口県は日本海と 瀬戸内海に面しており、施設整備状況も日本海側 2 県と瀬戸内海側 2 県との 中間的值を示すことより、山口県のデータを用い中国地方の推計を行うこ とは一定の合理性を有すると考える。

注13）全国学童保育連絡協議会の提言（2012.9)では、生活室・プレイルーム の面積を一人当たり $3.96 \mathrm{~m}^{2}$ 以上とする基準が提言されており、この基準を 適用すると、小学校の標準的教室面積 $63 \mathrm{~m}^{2}$ の場合施設定員は16名となる。 中山間地域では 20 人未満の施設が各々 $44 \sim 62 \%$ にぶことから、空き教室 あるいは同等以上の面積を有す学校以外の施設の場合には、現状でも協議 会提言基準を満足出来るケースが多いものと推定される。

注14）参考文献1) 資料5「生活の場」にふさわしい専用施設を、資料17学童保 育はどこで実施されているか(実施場所)を参照。

\section{参考文献}

1）全国学童保育連絡協議会編, 学童保育情報 2014-2015, 2014. 10

2）独立行政法人国民生活センター: 学童保育サービスの環境整備に関する調 查研究-都道府県の取り組みに大きな格差-, 2010.3

3）宮本文人·岩渕千恵子: 学童保育施設における活動機能と平面構成, 日本建 築学会計画系論文集, No. 618, pp, 25-31, 2007,8

4) 塚田由佳里・小伊藤覀希子: 施設空間と保育方法からみた学童保育所の分 割方法とその効果, 日本建築学会技術報告集, 第 27 号, pp, 223-228, 2008, 6

5）中園眞人・後谷一機他 2 名:農家納屋を改修した児童クラブハウス「つばめ の家」の夏休み期間中の使われ方, 日本建築学会計画系論文集, No. 698,pp. 965-972, 2014. 04

6) 山田あすか他 2 名:学童保育拠点における所要面積の算出に関する試論, 日本建築学会計画系論文集, No. 672,pp. 309 - 318, 2012.2

7）山崎陽菜・定行まり子:学童保育所における子どもの行為に要する面積か ら見た空間構成に関する研究, 日本建築学会計画系論文集, No. 682, pp. 2723-2728, 2012. 12

8）中川春香・山田あすか:学童保育拠点の運営実態の把握とそれに基づく人 数および面積規模に関する研究, 日本建築学会計画系論文集, No. 695, pp. 69-78, 2014. 1

9）塚田由佳里・小伊藤两希子：学童保育所の整備状況と地方自治体の対応か らみた施設整備課題, 日本建築学会技術報告集, No. 42, pp. 683-688, 2013.6 10）草野啓太・河田博之他 3 名：宇部市・松江市における学童保育施設の整
備状況と運営方式 学童保育施設の設置動向と水準評価に関する研究そ の 7, 日本建築学会中国支部研究報告集, No. 38,pp585-588, 2015.3 


\title{
SUPPLY SITUATION OF SCHOOLCHILD CARE FACILITY BY LOCAL GOVERNMENT AND ELEMENTARY SCHOOL UNIT IN CHUGOKU DISTRICT
}

\author{
Syohken KOH*, Keita KUSANO**, Mahito NAKAZONO***, \\ Sachiko YAMAMOTO ${ }^{* * * *}$ and Akira USHIJIMA***** \\ * Lect., Graduate School of Science and Eng., Yamaguchi Univ., Dr.Eng. \\ ** Naito Architects, M.Eng. \\ *** Prof., Graduate School of Science and Eng., Yamaguchi Univ., Dr.Eng. \\ **** Assist. Prof., Faculty of Eng., Info. and Systems, Univ. of Tsukuba, Dr.Eng. \\ ***** Assist. Prof., Graduate School of Science and Eng., Yamaguchi Univ., Dr.Eng.
}

The purpose of this study is to clarify the regionality of schoolchild care facility supply situation of the old local government unit and to estimate the number of registered children of the elementary school district unit in Chugoku district 5 prefectures, and to consider the supply method of schoolchild care facility for the future. The results are as follows.

1) Each old local government in 2000 was able to classify into five types, called Urban type, Flat-ground type, Middle type, Mountainous type A, and Mountainous type B. The old local governments classified into Urban type and Flat-ground type are located in a city area and they have more schoolchild than the old local governments classified into other three types. Although the establishment rate of schoolchild care facility in Urban type and Flat-ground type is over $100 \%$, other three types are under $100 \%$ and the disparity between urban type and mountainous type is large.

2) Generally, one schoolchild care facility is established at one elementary school. Then, the change in the number of registered children is considered, and more facilities are established newly when they are overcrowded. The classification of the old local government unit is applied to the elementary school district unit, and analysis is conducted about the relation between the establishment rate and the number of registered children. Consequently, clear relation was recognized between the local type and the establishment rate. In the elementary school district unit classified into Urban type and Flat-ground type, the number of schoolchild care facilities is corresponding and increasing to the number of registered children. On the other hand, in the elementary school district unit classified into other three types, one facility was established at one elementary school or there was no facility in one elementary school unit. In addition, although a schoolchild care facility is established in an elementary school by all the types in many cases, the rate that a facility is established out of an elementary school increases in Mountainous type A and B.

3) By estimating the number of one facility registered children for each elementary school district of Chugoku district 5 prefectures based on the data of Yamaguchi Prefecture, it is indicated that half of facilities in Urban type don't fulfill the new required conditions of one facility with 40 or less children and most facilities in Mountainous type A and B fulfill the new required conditions. 